\title{
Study Of Oral Traditions In The Development Of Social Science Teaching Materials For Grade Iii Of Elementary School In North Bali
}

\author{
I Wayan Mudana ${ }^{1}$, I Gusti Made Arya Suta Wirawan ${ }^{1}$, and I Putu Putra Yana Wardana ${ }^{1}$ \\ wayan.mudana@undiksha.ac.id \\ ${ }^{1}$ Universitas Pendidikan Ganesha, Indonesia
}

\begin{abstract}
This study aims to describe the forms of the oral tradition and the results of a critical study of the oral tradition. This study uses a qualitative approach. The forms of oral traditions that are still developing in society are folklore, folk proverbs, folk songs, and folk games. Oral tradition is one form of culture that has an important meaning in the inheritance of values that can contribute to the development of social studies in elementary school for low grades. Which, of course, will also be able to also contribute to the development of literacy. The oral tradition that develops in society has a meaning that not only has a denotative meaning but also has a connotative meaning. The meaning of oral traditions in cultural systems is very complex, related to economic, political, sociocultural, and environmental life.
\end{abstract}

Keywords: critical; oral; study; social; tradition

\section{Introduction}

Balinese society is an open society. The openness of the Balinese people has not only colored the multiculturalism of the Balinese people but has also caused the erosion of the traditional culture of the Balinese people, one of which can be seen in the existence of the oral traditions of the Balinese people. The erosion of oral tradition is also caused by the exclusion of oral traditions in social studies learning in elementary schools. The phenomenon causes the marginalization and alienation of oral traditions and the destruction of cultural values and people's personalities.

This phenomenon has prompted various studies of oral traditions. This can be seen, for example, from a critical study of oral traditions in the development of maritime literacy in elementary school students [18]. The study revealed the potential for oral traditions to be used as a basis for developing elementary school social studies teaching materials. The development of such an elementary school social studies learning model is a systemic effort to counter colonialist and American-centric social studies education, as stated by [21]. Especially in social studies learning during the New Order, which was centralistic. This is in line with the view of [7], who stated that during the New Order era, we as social science thought institutions had been weakened through authoritarianism so that there is no tradition of scientific autonomy (2016: 3-4).

This idea is in line with the development of a local culture-based learning paradigm. Because oral traditions contain values and moral messages that can support learning development, as the study conducted by Een Syaputra (2020). In the context of the 
Anthropology of Oral Literature, the study of oral traditions is seen as important in inheriting civilization[5]. Inheritance of local culture/oral tradition needs to be done early on. In this regard, efforts are made to develop teaching materials based on oral traditions in elementary social studies learning in lower grades.

The development of oral tradition-based elementary social studies teaching materials takes into account a) the relevance of the curriculum; b) richness of content; c) problems related to the school environment, so that meaningfulness is more optimal in understanding the socio-cultural environment and the formation of nation and character-building [8]. The most potential oral traditions to be included in learning are, for example, traditional expressions, folk poetry, folklore, folk games, and folk songs [27]. So that learning carried out in schools cannot be separated from social and cultural references from the community itself because the oral tradition contains social and cultural aspects [23]; [19]; [3]. This study focuses on traditional expressions, folklore, folk songs, and traditional games.

The study of oral traditions as the basis for developing teaching materials in line with the existence of educational institutions is an arena for cultural construction and deconstruction. Referring to the concept of constructionism introduced by interpretive sociologists Peter L. Berger and Thomas Luckman with their main thesis that humans and society are dialectical, dynamic, and plural products continuously (Berger and Luckman, 1990, 66-248; Eriyanto, 2008, 104 -118).

Teaching materials are important in the learning process, namely as a reference for students and teachers to improve learning effectiveness. For students, teaching materials become reference materials that are absorbed by their contents to become a source of knowledge. For teachers, teaching materials are references in delivering knowledge/materials to students [8]. Elementary Social Studies teaching materials developed in it contain learning materials and methods and evaluations designed systematically to achieve the expected learning objectives. Based on the background of this study, it seeks to describe the forms and results of critical social studies on oral traditions that developed in coastal communities in North Bali and their contribution to the development of social studies teaching materials for low-grade elementary schools in North Bali.

\section{Discussion}

The study of Balinese oral traditions can be seen from [2] studies in his study of the Culture of the Trunyan Village Farmers in Bali (1980) and Psychological Anthropology (1988), [6] on the interpretation of culture (1992), and Ni Nyoman Karmini, et al., in the book Unraveling Tradition. Oral Knitting Character Education (2013). From this study, it can be contributed to the development of the learning process.

By referring to the theory of oral tradition, it can be stated that the oral traditions that developed in North Bali society include folklore, traditional expressions, folk songs, and traditional games. Various forms of oral traditions owned by the people of North Bali are cultural capital that can contribute to the development of social studies learning in elementary schools in low grades.

The existence of oral tradition as cultural capital is in line with Pierre Bourdieu's thinking, which states that cultural capital is the possession of cultural knowledge that guides tastes with cultural values [1]; [9]. Education forms a person's cultural competence and knowledge which will become a preference in thinking, behaving, and behaving in people's lives. Cultural capital contains a set of values or norms that are embedded in various forms of oral traditions that live and develop in North Balinese society. 
Thus the oral tradition also contains moral dimensions in the socio-cultural life of the community. This kind of discourse allows the development of awareness of the preservation of traditional culture and allows the development of the character of the younger generation [10].

In this connection, cultural values, local wisdom, folklore, and traditional educational games are of great importance. In this context, the development of an oral tradition that is heavily loaded with cultural values/local wisdom can be fostered through the educational process. Of course, by positioning education as a cultural process and cultural therapy to prepare a generation with cultural understanding and awareness (Kartadinata, 2017: iii). Concerning the educational process borrowing ethnopedagogical ideas, it can be stated that in North-Bali society, there is an oral tradition of learning models of learning while megending (learning while singing), exploring while joking (learning while playing), exploring while megawe (learning while working), exploring while melali (learning while recreational), and exploring while mebalih (learning while watching).

Institutions as a component of social capital can be used to overcome the erosion of traditional culture and the fragility of the character of the younger generation. Various institutions in Balinese society can be used as an arena in the construction of traditional culture/oral traditions, such as family institutions, relatives, villages, and other village community self-help groups/institutions. This fact is in line with the conception contained in the theory of collective attitude. In a collective action, what determines a cultural, social, and economic activity is not individuals but the whole community in a regional or kinship system.

Based on this, it can be stated that in every cultural capital, there will always be two interrelated dimensions, namely the cognitive/cultural dimension related to values, attitudes, and beliefs that affect trust, solidarity, and reciprocity that lead to the creation of cooperation in society to achieve common goals. The second dimension is the structural dimension in the form of the arrangement of the scope of community organizations and institutions at the local level, which accommodates and encourages collective activities that benefit all community members.

In critically describing the socio-cultural capital of the oral tradition of the coastal communities of North Bali, it seems necessary to borrow the sociocultural concept developed by [11], who argues that universally culture has three forms, namely the cultural value system, social system, and physical culture. The same thing is also stated by [23], which states that the sociocultural system of society is divided into three: ideological superstructure, structure, and material infrastructure. Based on this, it can be revealed that coastal communities in North Bali have a fairly adequate cultural value system framed in the philosophy of rwa bhineda, and tri hita karana.

At the philosophical level rwa bhineda, the coastal communities of North Bali have an understanding that this natural environment is divided into two in a binary opposition level, lanang wadon (male-female), purusa pradana (male-female), kaja-kelod (north-south), kanginKawuh (East-West), kiwa-tengen (right-left), Segara-gunung (sea-mountain), awareness of the Balinese cosmic community can also be seen from the perspective of Tri Hita Karana, which contains the idea of awareness of the importance of developing structured environmental awareness in three dimensions, namely the theological environment, social environment, and ecological environment. Humans in their lives always interact with the three environments in a frame of harmony. It is through theological, social, and ecological harmony that the Balinese people realize their happiness. The perspective of tri hita karana in as one of the oral traditions that developed in Balinese society, of course, is not only seen from the denotative meaning but further than that, at least related to the connotative meaning because it does not only contain 
knowledge, there will be a need for a harmonious relationship human in the theological, sociological and ecological dimensions, but also understanding, critical attitude, and skills in overcoming various problems related to these three dimensions in human life. In that context, tri hita because it also contains the vision of developing theological, socio-cultural, and ecological literacy.

As is well known, the people of North Bali have the expression lanang wadon/purusa pradana (male and female). This expression is related to self-identity recognition. Self-identity recognition is an important thing in children's social life. In addition to self-identity, children also need to know about direction. In this context, the people of North Bali are familiar with the terms kaja kelod and kangi kauh. This expression needs to be understood by children in relation to the theme of making house plans.

Other expressions are related to territory, such as nyegara gunung. [15] revealed that nyegara gunung as the socio-cultural capital of the Balinese people, which has the denotative meaning of sea and mountain and has a connotative meaning as a living space, ecological intelligence. Awareness of the sea as living space can be seen from the expression of the Balinese coastal community, which states that uma abiane di pasihe (the fields are in the sea),

The awareness of the sea as living space can also be heard from the folk song of Juru Pencar. The lyrics of the song reveal the sea as a promising living space. The lyrics of the song are as follows: Juru Pencar, Juru Pencar, mai jani jalan ngejuk ebe, ebe gde gde, ebe gde gde di sowane ajaka liu. The lyrics of this song reveal the activities of catching fish, catching fish (Scatter/fishermen), and the existence of places to catch fish. The awareness of the sea as a living space increases the intensity of human relations with the sea. This further inspires the Balinese people to make the sea a living space with an economic dimension and a sociocultural dimension. The sociocultural dimension can be seen from the expressions of social control of the people of North Bali, such as ngentungan uyah ke pasihe or sekadi nasikin immediately. Another form of sociocultural capital is the social system. In the context of the social system, coastal communities develop various social groups, such as fishermen, fish traders, fish processing, ornamental fish, and fresh pecalang. These groups have the function of social integration and have the function of socialization/social construction and social control. People's lives in meeting their needs, the community develops market institutions. The existence of such an institution can be seen from the lyrics of the folk song Cening Putri Ayu. The lyrics of this song reveal family life, the existence of market institutions, and the role of parents and children in family life. These phrases and songs are in line with the themes discussed in elementary social studies learning in grade III, including the natural environment, the role of parents, the role of children, and buying and selling activities. Various forms of socio-cultural capital of coastal communities in Bali have denotative meanings and connotative meanings. This can be seen from several expressions that developed in coastal communities in Bali, such as the expression nyegara gunung, uma abine di pasihe, nasikin immediately, ngentungan uyah kepasihe, and so on. Awareness of the meaning contained in various forms of oral traditions as sociocultural capital will not only inspire coastal communities in utilizing the coastal and marine environment as living spaces, but also develop various forms of wisdom, social ethics, environmental ethics, technology, and various products - culture as a result of human creativity in responding to various environmental problems and coastal communities.

Other oral traditions that exist in the coastal communities of North Bali are in the form of folk games such as: mejukung-jukung, medagang-dagangan, megoak-goakan, cigcigbyak. This game is full of socio-cultural, economic, political, and cultural values. This kind of game can often be used as an arena for the development of elementary social studies learning both 
concerning efforts to basic knowledge about social relations, social norms, socio-economic activities, socio-politics, and the introduction of spatial awareness. Such basic concepts are certainly very important to be introduced in elementary social studies learning.

In the context of developing oral tradition-based social science learning in elementary school, it can simply be described as follows.

\section{FRAMEWORK MODEL FOR THE DEVELOPMENT OF TEACHING MATERIALS} BASED ON ORAL TRADITION

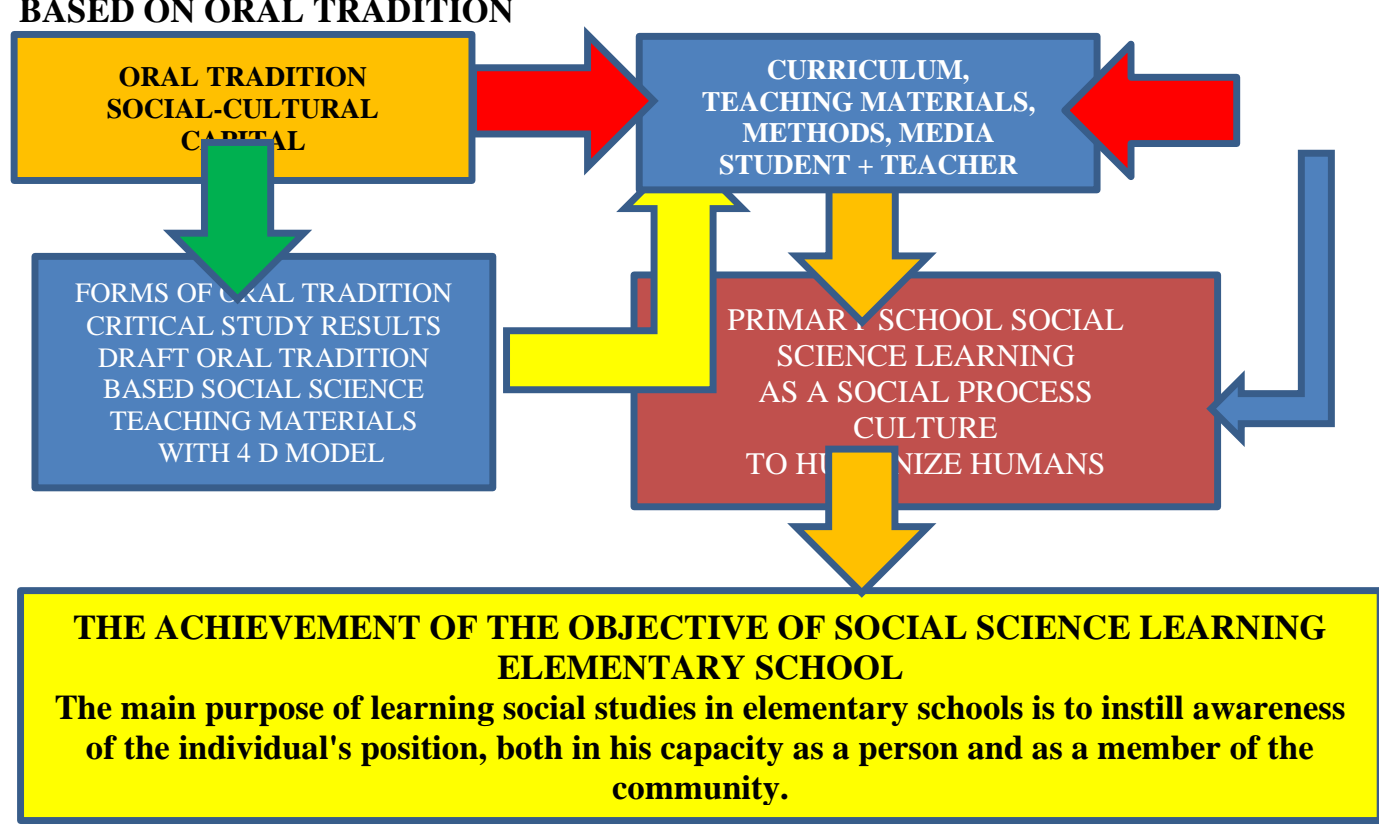

\section{Conclusion}

Based on this description, it can be concluded that the forms of oral traditions that are still developing in society are folklore, folk proverbs, folk songs and folk games. Oral tradition is one form of culture that has an important meaning in the inheritance of values that can be contributed to the development of social studies learning in lower grade elementary schools. The teaching language developed is based on the Balinese oral tradition. Oral tradition not only color the packaging of teaching materials but also the packaging of the elementary social studies learning process in lower grades, such as through the process of learning while singing, learning while playing, learning while working, studying while watching and traveling/recreation. Which of course will also contribute to the development of literacy. The oral tradition that develops in society has a meaning that not only has a denotative meaning, but also has a connotative meaning. The meaning of oral traditions in cultural systems is very complex, related to economic, political, socio-cultural, and environmental life. 


\section{References}

[1] Damsar dan Indrayani, 2019. Pengantar Sosiologi Kapital. Jakarta: Prenadamedia.

[2] Danandjaja, James. 1998. Pendekatan Foklor dalam Penelitian Bahan-Bahan Tradisi Lisan, dalam Metodologi Kajian Tradisi Lisan, Pudentia MPSS (ed). Jakarta: Yayasan Obor Indonesia dan Yayasan Asosiasi Tradisi Lisan.

[3] Danandjaja, James. 1998. Antropologi Psikologi, Teori, Metode dan Sejarah Perkembangannya. Jakarta: Rajawali Press.

[4] Dove, Michael R. 1985. Peranan Kebudayaan Tradisional Indonesia Dalam Modernisasi. Jakarta: Yayasan Obor Indonesia.

[5] Endraswara, Suwardi. 2018. Antropologi Sastra Lisan. Perspektif, Teori dan Praktik . Pengkajian. Jakarta: Yayasan Obor Indonesia.

[6] Geertz, Clifford. 1992. Tafsir Kebudayaan. Yogyakarta: Kanisius.

[7] Hadiz, Vedi R. 2016. Ilmu Sosial dalam Konteks Otoritarisme, Demokrasi dan Tuntutan Pasar. Dalam Ilmu Sosial di Indonesia Perkembangan dan Tantangan (Widjajanti Mulyono Santoso (ed). Jakarta: Yayasan Pustaka Obor Indonesia.

[8] Hutama, F, 2016. Pengembangan Bahan Ajar Ips Berbasis Nilai Budaya Using Untuk Siswa Sekolah Dasar. Dalam Jurnal Pendidiklan Indonesia. P-ISSN: 2303-288X EISSN: 2541-7207 Vol. 5, No.2, Oktober 2016

[9] Hasbullah, Jausairi 2006. Social Capital (Menuju Keunggulan Budaya Manusia Indonesia). Jakarta: MR-United.

[10] Karmini, Ni Nyoman, dkk., 2013. Mengurai tradisi Lisan Merajut Pendidikan Karakter. Denpasar: Cakra Press

[11] Koentjaraningrat. 1981 . Pengantar Antropologi. Jakarta: Aksara Baru.

[12] Lapian, Adrian B. Orang Laut, Bajak Laut, Raja Sejarah Kawasan Laut Sulawesi Abad XIX. Jakarta: KITLV.

[13] La Ode Ali Basri, I Wayan Mudana, Abdul Rahman. 2017. The Negative Stigma Against the Bajo Tribe and its Impact on Local Culture: Study of the Bajo in Bungin Village of South Konawe.

[14] La Ode Ali Basri, I Wayan Mudana, Abdul Rahman. 2017. The Negative Stigma Against the Bajo Tribe and its Impact on Local Culture: Study of the Bajo in Bungin Village of South Konawe.

[15] Mudana I Wayan. 2014. Ideologi Nyegara Gunung (Penelitian Hibah Stranas-Dikti). Singaraja: Undiksha.

[16] Mudana, I Wayan. 2018. Critical Social Analysis of Maritime Cultural Contruct of Pedagogiy in Bali Coastal Area Elementary School Student.

[17] Mudana, I Wayan, dan La Ode Ali Basri. 2018. Collaboration of Economic Community, Political Community, and Civil Community in Ivestation Social Capital, For Preservation of Marine and Coastal Environment in The Pemuteran Village, Bali .

[18] Mudana, I Wayan.2020. Kajian Sosial Kritis Tradisi Lisan Masyarakat Pesisir Dalam Pengembangan Literasi Bahari Pada Siswa Sekolah Dasar di Bali Utara (Penelitian Dipa). Singaraja: Undiksha

[19] Pudentia MPSS. 1988. Metodologi Kajian Tradisi Lisan. Jakarta: Yayasan Obor Indonesia dan asosiasi Tradisi Lisan.

[20] Rahardjo, 2002. "Puasa Sumber Reproduksi Modal Sosial” .Jakarta: Harian Kompas

[21] Samuel, Haanneman. 2010. Geneologi Kekuasaan Ilmu Sosial Indonesia Dari Kolonialisme Belanda Hingga Modernisme Amerika. Depok: Kepik Ungu. 
[22] Sanderson, Stephen K. 1999. Sosiologi Makro Sebuah Pendekatan Terhadap Realitas Sosial. Jakarta: Rajawali Pers.

[23] Sedyawati, Edi. 1998. Sastra dalam Kata, Suara, Gerak, dan Rupa. Dalam Metodologi Kajian Tradisi Lisan, Pudentia MPSS (ed). Jakarta: Yayasan Obor Indonesia dan Yayasan Asosiasi Tradisi Lisan.

[24] Sobary, Mohammad. 2000. Kealehan Sosial. Yogyakarta: LkiS.

[25] Sumitri, Ni Wayan. 2016. Tradisi Lisan Vera: Jendela Bahasa, sastra, dan Budaya Etnik Rongga. Jakarta: Yayasan Obor Indonesia.

[26] Sunarti, Sastri. 2013. Kajian Lintas Media Kelisanan dan Keberaksaraan Dalam Surat kabar Terbitan Awal di Minangkabau (1859-1940-an). Jakarta: KPG

[27] Syaputra, Een. 2020. Tradisi lisan sebagai bahan pengembangan materi ajar Pendidikan IPS di SMP: sebuah telaah literature, dalam Jurnal Teori dan Praksis Pembelajaran IPS, Volume 5, No.1, Tahun 2020, Halaman 51-62, P- ISSN: 2503-1201; E-ISSN:2503-5347

[28] Vickers, Adrian. 2009. Peradaban Pesisir Menuju Sejarah Budaya Asia Tenggara. Denpasara: Udayana Universitas Press.

[29] Zuhdi, Susanto. 2014. Nasionalisme, Laut, dan Sejarah. Depok: Komunitas Bambu. 